\title{
Solar Energy Initiatives and its Positive Impacts on African Nations (SADC and Nigeria): A News Review
}

\author{
Chima Ichendu $^{1 *}$, Dennis Ejike Amadi ${ }^{1}$ \\ ${ }^{1}$ Department of Architectural Technology, Port Harcourt Polytechnic, Captain Elechi Amadi Polytechnic, Rumuomei 100001, Port Harcourt, Nigeria
}

DOI: $\underline{10.36348 / \text { sjet.2021.v06i04.001 }}$

| Received: 02.03.2021 | Accepted: 19.03.2021 | Published: 06.04.2021

*Corresponding author: Chima Ichendu

\section{Abstract}

This paper provides a summary overview of the benefits of training and retraining of students and staff of Universities in Africa through the adoption of solar energy sources of electricity generation as a form of renewable energy technologies. The paper appraises the impact of the introduction of solar energy technologies on a student of Lesotho, his supervisor and the community. Through news review, the paper uses trending news as a scope within a given period to trace the impact of the initiatives by Southern African Solar Thermal Training and Demonstration Initiative (SOLTRAIN), an initiative of the Austrian Development Agency (ADA). Further the paper appraises trending news through the review of the key features particularly the initiatives contributions to the end users. In comparison, the paper presents the basic characteristics from the initiatives by SOLTRAIN and the Federal Government of Nigeria to the developments of skills as well as training institutions amongst the key elements that contribute to national growth. Conclusively, the reports identifies key drivers that are likely to decide the future direction of the solar energy expansion within the nation.

Keywords: Solar, energy, initiative, technology.

Copyright (C) 2021 The Author(s): This is an open-access article distributed under the terms of the Creative Commons Attribution 4.0 International License (CC BY-NC 4.0) which permits unrestricted use, distribution, and reproduction in any medium for non-commercial use provided the original author and source are credited.

\section{INTRODUCTION}

In a bid to educate the populace and Nigerian Universities communities of the positive impacts of solar energy, it becomes imperative to track trending stories within the solar energy initiatives around Africa. This report took inventory of solar water heaters manufactured locally with global recognition by a student of the National University of Lesotho (NUT), who designed a water heater locally with locally available materials as well as skills. This water heater is an eco-friendly system made specifically for local houses to reduce the amount of electricity consumption and dependence on fossil fuels as sources of energy. This was achieved through the support of Southern African Solar Thermal Training and Demonstration Initiative (SOLTRAIN), an initiative of the Austrian Development Agency (ADA), targeted at ensuring that the Southern African countries partake fully in the global renewable energy fuel sources.

Furthermore, reporting another inventory within the Nigerian context, in this case, the Federal Government of Nigeria in partnership with a Greekbased Energy Company to power four universities communities and her teaching hospital with solar power kits. This has become significant considering the continuous power outages and the load overbearing the national grid, which is made up of unsustainable nonrenewable energy sources.

This essay reports news on a few media channels where SOLTRAIN's impact is felt within the SADC countries. These media channels include the National University of Lesotho (NUT) media (2016) [1], the Global Energy Council (GLC) 2016, Technology Energy Development (TED) (2016), and the Southern Times (2016) as well as PV magazine. It is a storyline of an event tracked through a specific duration; hence, the essay traced the SOLTRAIN impact within the SADC region up to July 2016 and the activity of the Federal Government of Nigeria in signing an engineering, procurement and construction contract with Metka Power West-Africa. The essence of this storyline is to bring to the fore the advantages of the advancement of solar energy components towards the development of our Nigerian Universities and consequently, make them less dependent on fossil fuelbased sources of electricity generation. The first part of this storyline essay is the account and impact of the activities of SOLTRAIN, followed by the account of the gains associated with the signing of the contract 
Chima Ichendu \& Dennis Ejike Amadi, Saudi J Eng Technol, Apr, 2021; 6(4): 53-56

between the Nigerian Federal Government and Metka. Furthermore, the advancement of the Nigerian government fulfilling their pledges and the universities connected to off grid solar powered electricity.

\section{Solar water and SOLTRAIN initiative}

In view of an event hosted in Germany as reported by the Global Thermal Energy Council dated October 1, 2016, and titled Germany International Conference on Heat Access in Southern Africa, a proposal was made to enhance the deployment of solar technology including photovoltaic in developing countries. This event took place in Bad Hersfeld near Frankfurt, Germany. The representation of experts from Southern African countries was in a good number pioneered by Southern African Solar Thermal Training and Demonstration Initiative (SOLTRAIN). The figure below is the group portrait of participants in Germany [2].

The critical aspect of this event was the SOLTRAIN initiative of bringing Southern African countries (Botswana, Mozambique, Namibia, South Africa and Zimbabwe) to contribute to the reduction of the amount of energy consumed in their local communities. This was achieved through the inclusion of solar water heater and solar electrification in their homes through local inventions (manufacturing) of these products by their members, not excluding interested parties.

Also, smaller groups and institutions willing to participate would receive a fair opportunity to make a useful contribution(s) in line with their agenda of reducing the demand on unsustainable non-renewable sources of electricity generation. According to Werner Weiss, (SOLTRAIN's project coordinator) when homes have access to the grid, they consume about $50 \%$ of their electricity for hot water. Further, households that combine solar energy sources reduce the amount of electricity consumed to attain comfort. This is the benchmark for the formation of SOLTRAIN as an agent to train participants and organize a series of campaigns and enlightenment programs tailored at saving energy and reducing the amount of money households spend on electricity.

The fantastic side of the news is the production/manufacturing of the water heater for lowincome households in Lesotho by Mr Anadola Tsiu, a student in the Department of Physics and Electronics, The National University of Lesotho, Media, 2016. With the assistance of the laboratory technician, he manufactured a simple prototype 50-litre water heater for low households and those living within the hinterlands of Lesotho, as shown in figure 3.

The water heater component includes a " $1.35 \mathrm{~m} 2$ collector insulated with raw sheep wool, equipped with a galvanized one millimeter $(1 \mathrm{~mm})$ copper absorber and covered by an ordinary windowpane" ( Up, 2016: unpaginated).

The system is made with remote tracking to monitor its performance, and the water temperature is monitored from their cell phones despite their locations. This adventure triggered SOLTRAIN to embark on more phases of solar water projects within some SADC member nations, with a total project budget of three million four hundred Euros (EUR. 3.4m). The solar water heater project brought NUL to the limelight as the institution celebrated the award. The University media reports that their institution came out second after a Canadian contestant took first. The institution in their news bulletin stated that despite the product winning an international award amongst other benefits, the profound one is its service to an 80-year-old woman living in the remote community of Lesotho [3].

The water heater is $100 \%$ made in Lesotho and called the Flat plate solar thermal energy collector, which is the fascinating aspect of the device. Although it is a locally manufactured product with international recognition and award, the institution in amazement states that; how does a product made in the oftenoverlooked Lesotho convince judges from around the world? As they explained their decision, the judges mentioned three factors that captured their attention about the National University of Lesotho (NUL) made system. They said; "It uses simple technology, performs just as a complex international commercial technology, and can make an immediate impact on people's lives", NUL media (2016: unpaginated) [3].

SOLTRAIN continues in their quest to deliver on their promises within the Southern African region. Although this is not the focus of this report, the impact of the contribution of SOLTRAIN in the development of the solar water heater attracted further findings into what they are doing. However, the report will mention and cite their contribution in pictorial and in few words. SOLTRAIN is founded by the Austrian Development Agency (ADA), whose objective is to reduce the amount of dependency on fossil fuel sources of energy generation by a renewable energy base. Figure 5 and 6 show a pictorial display of some projects by SOLTRAIN. This trailer is equally another locally manufactured product supported by SOLTRAIN made within the SADC region to aid demonstration, teaching, training and campaign.

\section{Federal Government of Nigeria Signing Engineering, Procurement and Construction (EPC) Contract with Metka}

In the Nigerian context, significantly, the Federal Government taking the responsibility of reducing the workload on the national grid is a welcomed development. Hence, mini-grid initiatives would grow, the continuous power outage will be limited, and communities and those residing on the 
Chima Ichendu \& Dennis Ejike Amadi, Saudi J Eng Technol, Apr, 2021; 6(4): 53-56

hinterland of the nation can be lit through solar energy technologies. The Nigerian Government had an agreement with Metka where the Federal Government of Nigeria bears the funding and Metka takes the responsibility of the technical and engineering aspect of installing a mini-grid of 9.3 megawatts PV system and 5760 battery cell for four Nigerian Federal Universities and their respective teaching hospitals as well as training of teachers and students respectively. The names of these Universities were not mentioned, but it is an innovation in the right tracks for the Nigerian University communities.

As mentioned earlier, Universities in the SADC region had similar contracting agreements, although the funding here differs. However, the impact to the local content is similar; students and lecturers will be trained during construction and postconstruction stages, it will generate electricity to power the University's community, as well as provide streetlight within these campuses and become a training facility for energy courses after the contract is executed. This implies that at the post-contract stage of this project, the selected University campuses will run offgrid, hence, giving room for other areas to be connected to the national grid [4].

In another development, Hephzibah [5] reported that the Centre for Energy Research, University of Nigeria Nsukka, through her students, developed a computer-aided pure sine wave solar inverter. These students were five, who despite their scheduled academic activities, dedicated more of their time into thorough research over several years [5]. The inverter grades range from lower to a higher power of about 1500Watts through 30,000Watts in a single generation. The inverter also has a menu-driven thunder detector when fully loaded and could respond in short circuit. Significantly, it is a local, eco-friendly sustainable means of providing electricity from solar and is not dependent on energy from the national grid. According to Hephzibah [5], the first set of products are completely sold and have been in use for almost a year.

In subsequent news, the promise made by the Federal Government of Nigeria was actualized in several Universities. Fatunde [6] and Adewale [7], reported that the University of Ibadan commissioned a 10MW solar plant (a partnership project by the Nigerian Government and German International Cooperation Organization (GIZ) who supervised the project. In another development, the presence of the Federal Government of Nigeria is felt in the University of Nigeria Nsukka [8]. According to Fatunde [6], there was excitement in the University community when the launching of the 100kVA refuse-derived fuel (RDF) gasification plant was commissioned.

Before this initiation, the University, through her engineering research team, was working on developing a 12250kVA plant whose initial intentions were to supply the University community and her neighbours with electricity produced from solar energy. Fatunde [6] further emphasized that the energy need of the University is just 3MW; hence, the $12250 \mathrm{kVA}$ RDF plant in the University automatically runs on its own mini-grid.

Furthermore, these initiatives by the Federal Government were felt in Bayero University Kano as well, where a 7.1MW solar hybrid power project was commissioned. The commissioning of the $7.1 \mathrm{MW}$ plant makes the University enjoy 24 hours of electricity supplied via solar energy and off the national grid. This enhances the teaching, learning and research work of the institution. This initiative was borne by the Federal Government of Nigeria in partnership with the Energizing Education Programme (EEP) through the aid of the Nigerian Rural Electrocution Agency (REA) [6].

\section{CONCLUSION}

The SOLTRAIN initiative is a welcomed development, especially as it brings a renewable and sustainable campaign to Southern African countries. Globally, renewable energy and technology have made a tremendous impact, which is felt within the rural communities through sensitization and awareness campaigns. In line with the global stride towards the reduction of $\mathrm{CO}_{2}$ emissions and continuous reliance on fossil fuel-based energy generation and consumption, the path trod by SOLTRAIN with the help of the Austrian Development Agency (ADA) is a very vital one, especially, as rural communities and hinterlands can now benefit through renewable energy products as well as its production. However, it is imperative to keep the light shining through more awareness campaigns, training and retraining of those that have acquired the skill(s).

The major obstacle to the uptake of this innovative idea includes a lack of funds and goodwill support for those who are ready to venture, such as $\mathrm{Mr}$ Tsiu. The National University of Lesotho (NUL) should not just enjoy the award and certificate. However, a proper partnership should be meted on the institution, at least to encourage mass production, which will create room for the availability and affordability of the solar water heater to all and sundry.

The initiative by the Federal Government of Nigeria is a significant stride as it helps the Universities to become eco-friendly, and provides electricity selfsufficiency and a training ground for lecturers and students as well as researchers within the field of solar energy. The facility will serve as a pioneer laboratory for the advancement of renewable energy within the nations. Unlike the case of the SADC, the Nigerian scenario has less obstacles as the Federal Government takes charge of the funding and the Metka takes the 
Chima Ichendu \& Dennis Ejike Amadi, Saudi J Eng Technol, Apr, 2021; 6(4): 53-56

responsibility of engineering and construction as well as training of the members of the University. Furthermore, there is a strong indication that solar energy around Africa is untapped [9]. Considering the trend in the improvement of solar energy technology so far, a precise and targeted campaign in this context would be beneficial.

\section{RECOMMENDATION}

- More of these initiatives should be meted in all Nigerian higher Institutions/Universities, especially technologically-based, towards the advancement of sustainable energy practice as well as the reduction of energy from fossil fuel-based energy plants.

- Students and lecturers from Nigerian Polytechnics and Universities should be given an adequate grant for further research in solar energy advancement technologies.

- More training facilities should be built in Universities of Technologies, Polytechnics, Technical Colleges and Vocational Education Centres.

- Individuals, corporate organizations, industries and private sectors should partner with the Government to facilitate electricity for all through investments in solar energy technologies and rural electrification projects.

- Laws, policies and reforms with matching implementation and enforcement strategies favouring rural electrification should form the basic bills in the floor of the local Government, state and the national legislative assembly.

- Adopting a business model and an international mechanism that will foster smooth integration of PV technologies within those living within the hinterlands should be encouraged by the Government of the day.

\section{REFERENCES}

1. National university of Lesotho, medis. (2016, 09 29). National university of Lesotho media. Retrieved from National university of Lesotho media: http://www.thereporter.co.is/2016/09/29/lesot ho-university

2. Southern Times. (2016, September 22). The south africa times. Retrieved from the south africa times (the news paper for southern africa: hppt://southerntimesafrica.com/

3. National, U. L. (2016, 09 09). National university of lesotho media. Retrieved 12 12, 2016, from national university of lesotho media:

https://wwwthereporter.co.is/2016/lesothouniversity-media

4. Tsagas, I. (2018, 07 07). Nigerian Universities go off-grid with solar PV, storage mini-grids. Retrieved from Nigerian Universities go offgrid with solar PV, storage mini-grids: http://www.prividaenergy.com/2018/17/18/nig erian-universities-go-off-grid-with-solar-pvstorage-mini-grids/

5. Hephzibah, Emeka. (2019, November 29). Solar inverter made in nigeria-vangard News. (s. i.-v. News, Producer, \& Vangard News) Retrieved july 21, 2020, from solar inverter made in nigeria-vangard News: www.vanguardngr.com

6. Fatunde, T. (2019, Novermber 02). Universities embrace altenative power sources. Retrieved july 21, 2020, from University world news: universityworldnews.com

7. Adewale, S. A., Badu-Apraku, B., Akinwale, R. O., Paterne, A. A., Gedil, M., \& GarciaOliveira, A. L. (2020). Genome-wide association study of Striga resistance in early maturing white tropical maize inbred lines. BMC plant biology, 20, 1-16.

8. Murtula, A. (2019, 09 28). BUK solar project: FG revolutioning education through off-grid power. Retrieved 07 21, 2020, from Guardian Newspaper: t.guardian.ng

9. World Energy Resources. (2016, 01 01). World energy resource. Retrieved from world energy council: www.worldenergy.org/@WECouncil. 